\title{
Collaborative Innovation in Agrometeorology: Coordination Strategies to Develop a Monitoring IT System for Brazil
}

\author{
Martha Delphino Bambini', Priscila Pereira Coltri², André Tosi Furtado ${ }^{3}$, Jurandir Zullo Junior ${ }^{4}$
}

\begin{abstract}
This case-study article presents the results from a morphology analysis of a knowledge and information network, focusing on the coordination mechanisms employed to generate a convergent arrangement. Agritempo was the first information system to offer (in 2003) free access to a broad range of agrometeorological data comprising all the Brazilian territory, representing an important technological innovation to the agricultural sector. To study this phenomenon an analytical framework of the Techno-Economic Network (TEN) and concepts from the Innovation Sociology field was employed. Results indicate that the durability of this arrangement - from 2003 to 2014 - can be explained by the effectiveness of the coordination strategies established in the network such as: trust based relationships; institutional and individual leadership actions; contracting; software applications and shared common working procedures.
\end{abstract}

Keywords: techno-economics networks; innovation; agrometeorology; information and communication technology.

\footnotetext{
'Analyst at Embrapa Informática Agropecuária, Av.André Tosello, 209, Barão Geraldo, PO BOX 604I, Zip Code I3083-886, Campinas/S.P., Brazil. Phone +5519321 I5741. e-mail: martha.bambini@embrapa.br

${ }^{2,4}$ Researcher at Center of Meteorological and Climate Researches Applied to Agriculture (Cepagri) at State University of Campinas (Unicamp)

${ }^{3}$ Professor at Scientific and Technological Policy Department (DPCT) at State University of Campinas (Unicamp). R. João Pandiá Calógeras, 5I, Cidade Universitária, Zeferino Vaz, Zip Code I3083-970, Campinas/S.P. , Brazil.
} 


\section{Introduction}

Weather has an important impact in agricultural production. It has a straight influence on crop growth, development and yields; on the incidence of pests and diseases; on water needs; and on fertilizer requirements. Extreme and variable weather conditions may cause decline in production, damage to crops and soil erosion, decline in the quality of the final products, problems in the yield transportation and so forth. In addition, weather conditions strongly influence the performance of agricultural practices, such as soil preparation, seeding, fertilization, irrigation, application of pesticides and harvesting.

Thus, there is no aspect of crop culture that is immune to the impact of weather. These impacts are particularly strong in developing countries located in the tropics with low levels of crop management technology, and in most of the cases, exposed to high variability in climate because of regional meteorological systems and phenomena.

Considering this context, it is crucial to use weather and climate information to support the decision making process at various dimensions: at the farm, in agricultural industries and for governmental planning (local, state and federal levels). Moreover, the existence of organized and reliable databases is necessary to develop studies and research in Agrometeorology, to generate new knowledge and technological alternatives to minimize the effects of adverse weather and climate conditions for agriculture.

This article presents the results of a research project conducted from 2009 to $201 \mathrm{I}$ that mapped and analyzed the dynamics of a collaborative innovation network formed to develop an agrometeorological information web system for Brazil. The Agrometeorological Monitoring System (Agritempo) was the first information system to offer free access to a broad range of agrometeorological data and maps comprising all the Brazilian territory (http://www.agritempo. gov.br). It was published as a website on the Internet in 2003 , becoming a significant technological innovation for agricultural sector.

Given that Brazil is a country of continental proportions (with an area of 8,5 million $\mathrm{km} 2$ ), until the 2000's it was almost impossible to coordinate all the actors of the meteorological sector in order to provide and share data and information to cover the entire country. Thus the system also appears as a significant process innovation once it promoted the exchange of data from about 40 partners, collected from various kinds of instruments, in different formats, and stored them in a consolidated database of meteorological data.
The Techno-Economic Network (TEN) analytical framework and Innovation Sociology related concepts developed in the 1990s were employed to study and understand innovation processes occurring in European Research Projects (Callon, et al, 1992; Callon, et al, 1995) by authors of the Innovation Sociology field (Akrich, et al, 1988). The innovation network, as an inter-organizational arrangement, describes successfully the interactions among several actors - researchers, engineers, investors and users - promoted to generate scientific and technological creations that are disseminated to market agents.

This paper aims to map the knowledge and information generating processes through the analysis of the morphology of the network, focusing on the strategies employed to coordinate the activities and interests of the involved actors. The network mobilized by the system involved the coordinated effort of more than 40 organizations related to Meteorological and Agrometeorological sectors, comprehending around I,380 weather observation stations. For the development and structuring of a database with national coverage, it was necessary to mobilize expertise, data, equipment and financial resources and promote interactions and coordination among all these heterogeneous actors (public research institutions, universities, businesses, government agencies and end users).

The Agrometeorological system was a result of a joint research project leaded by Embrapa Informática Agropecuária (http://www.cnptia.embrapa.br), which is a research center of the Brazilian Agricultural Research Corporation (Embrapa), in partnership with the Center for Meteorological and Climate Research Applied to Agriculture (Cepagri), a research unity of the State University of Campinas (Unicamp) (http://www.cpa.unicamp.br). Several Research Institutes, Universities, Governmental Agencies, Meteorological Services (and even farmers) worked collaboratively to strengthen Agritempo's meteorological data base aiming to provide agrometeorological informational products comprehending all the Brazilian regions and States. Some of the informational products of Agritempo System are: weather forecast, plant health treatment, drought, probability of rain and so forth. The objective is to support agricultural practices by offering weather and climate information in a friendly and accessible format.

Considering the challenge of coordinating Governmental Meteorological Services, which were dispersed between the Ministry of Agriculture, Livestock and Food Supply (MAPA), Ministry of Science, Technology and Innovation (MCTI) and the Brazilian Navy, the analysis of the case of Agritempo system demonstrates that is possible to integrate all these organizations in order to generate scientific results and technological products, contributing to the establishment of public policies related to the agricultural sector. 
The next section presents an overview of the existing literature related to networks and innovation and the specific theoretical concepts and constructs employed in this research. The subsequent section outlines the research design and methods, followed by the description of the studied case, the empirical evidence and its discussion. The final section describes the conclusions and future development.

\section{Literature overview: Innovation \& Networks I.I Evolution in the understanding of the concept of innovation through the ages, considering the per- spective of collaboration}

Since Kline \& Rosenberg (1986) up to Chesbrough (2003), many studies have described the interactive, adaptive and multifaceted nature of innovative processes, involving negotiations and exchanges of several types of actors in flexible and less hierarchical arrangements. Some of the actors that interact in innovative processes are research institutes, universities, private companies, and government agencies, among other organizations

The chain-linked model, described by Kline and Rosenberg (1986) in the 1980s emphasize the importance of interactions and feedbacks between different departments of a given firm participating in the innovation process, such as product specification, product development, production, marketing and distribution. The feedback interconnect the perceptions of several professionals from different areas of the firm and even the users and customers, identifying market demands, possible technical solutions and performance gains through multiple rounds of design.

In the 1990s, several authors from different fields of study emphasized the collaborative aspect of innovation processes, which goes beyond the organizational boundary of the firm and involves the formation of alliances, cooperation and collective arrangements between several actors (Akrich, et al, 1988; Freeman and Soete, 1997). In this period, a number of studies have addressed the theme of innovative networks (Powell, 1990; Debresson and Amesse, 199I; Freeman, 199I; Powell, et al, 1996).

According to Powell, et al, (1996), "a network serves as a locus for innovation because it provides timely access to knowledge and resources that would not be otherwise available" (p.l19). The authors specify some motivations to establish a cooperative agreement: faster access to new markets or technologies, economies of scale resulting from research or joint production; new sources of know-how and expertise located outside the boundaries of the firm; and sharing risks of activities that are beyond the scope or capacity of a single organization. Aruja (2000) points out some of the benefits of networking such as resources shar- ing and the combination of knowledge, skills and physical assets of several partners. Additionally, the participation in innovation networks can provide direct access to spillovers that provide information on new discoveries or insights to solve problems.

Innovation networks are flexible organizational arrangements and comprises recombining inter-relationships that can provide distinct advantages to firm. It can assume various formats and nomenclatures: joint ventures, networks between suppliers and users, Research and Development - R\&D partnerships, regional networks, strategic alliances (Debresson and Amesse, 1991; Powell et al, 1996). Each network is shaped and customized according to the interests and the needs of the parties and to the types of skills and shared resources involved. Institutional and economic context as well as tax and regulatory issues can also influence the morphology of the arrangements.

The collaborative innovation model comprises the existence of several ways of multilateral governance, more flexible and milder, characterized by reciprocity, reputation of the members, trust relations, asset complementarity and common goals. The network format allows each actor to maintain its original identity and personality and, at the same time, stimulates innovation through collaboration.

Inside network it may be possible to find some degree of hierarchy as well as distributed governance. Specific factors encourage collaboration among organizations: repeated interactions between partners, the possibility of future partnerships and reputation (what becomes a reference of the reliability of the partner). In these cases, there is little need for hierarchical supervision, because the desire to continue the partnership discourages opportunism; in this case, the network may be supervised by the partners themselves (Powell, 1990).

In the 2000s, the "Open Innovation" approach - coined by Chesbrough (2003) - has been since then presented and adopted by several companies as a strategy for business competitiveness. This paradigm, in the words of Chesbrough (2004), assumes that firms can and should use external sources of ideas and internal as well as internal and external channels to market in order to advance their technologies. Ades et al (2013) describe three that factors strongly influence the adoption of Open Innovation models by traditional companies: organizational culture, strategic and interactive capabilities of personnel and motivation (low resistance to the open model and existence of rewarding instruments).

Some authors consider that the open innovation repeats "old concepts with new clothes". Gassman (2006) stresses that "open innovation is not an imperative for every com- 
pany and every innovator". On the contrary, a contingency approach is needed, considering the idiosyncrasies of each economic sector, each industry and each type of audience and market, among other factors. Trott and Hartmann (2009) emphasize that cooperation and alliances between firms are nothing new. Besides that they argue that it is clear that Chesbrough (2003) has been very successful in popularizing some concepts related to the need of share and exchange of knowledge, as well as technology transfers among organizations in order to generate innovations. Clearly this notion have reached new audiences such as Chief-Executive Officers and Directors of technology-intensive companies, from a business strategy perspective.

Valkokari et al (2009) discuss the concept of networked innovation, based on the degree of openness and interaction of a given innovation system. They define "networked innovation" as collaborative activities and joint development of innovations promoted by multiple actors. Their research considers networked innovation as hybrid arrangements containing hierarchical and market coordination elements, represented by control-governance and self-organization, with both weak and strong relationships among actors. The authors pinpoint that the analysis of the coordination mechanisms employed by the actors are critical to understand how the networked innovation would format the role and structure of a given firm.

Pellegrin et al (2010) describe the phenomena of Induced Innovation Networks (IINs), as the promotion of linkages among several actors of a given country or region by the coordination mechanisms of governments. These efforts are conducted in order to improve firm's competitiveness and the maturation of Innovation Systems, based on the assumption that governments, firms, universities, research centers and financial agents have different responsibilities, roles and contributions to foster innovations. The IIN refers to a strategy to improve synergies among actors in order to provide a more effective use of resources in the innovation process. It can be compared to a public policy innovation and would probably be more effective in emerging countries where sectoral innovation systems are not well developed and established. In general, local and/or national governments represents collective interests, by developing public policies, acting as a Coordination Center, in order to reduce complexity of the relationships and also of the risks associated to innovation.

Table I presents the evolution of the several theoretical approaches towards innovation, interactivity and inter-organizational networks developed in the past decades. Even though the changes regarding the type of actors and the forms of collaboration involved in the generation of new knowledge and technologies, it is well established that the innovative process is more and more characterized in the literature as a collective initiative, rather than the result of isolated efforts of inventors and scientists (Akrich, Callon and Latour, 1988; Freeman and Soete, 1997). Some of the motivations for this trend are: a substantial increase of complexity in technological development processes; the asymmetry in access of various sources of knew knowledge and information as well as to the limitation of resources (financial, human and so forth).

In the twenty-first century, the locus of innovation is, in general, a collective arrangement that involves interaction, adaptation and negotiation, as well as the establishment of socio-technical commitments, among several actors. As the literature review shows, relationships and coordination strategies are at the center of collaborative innovation activities. In this article the sociology of innovation conceptual framework was adopted to understand how relationships were established and coordinated in this case study.

\begin{tabular}{|c|c|c|}
\hline Decade & Key-ideas & Works \\
\hline $\mathbf{1 9 5 0}$ & Linear Model of Innovation & Science the endless frontier (Bush, 1945) \\
\hline $\mathbf{1 9 6 0}$ & Communications \& diffusion of innovation & Diffusion of Innovations (Rogers, 1962), Learning by doing (Arrow, 1962) \\
\hline $\mathbf{1 9 7 0}$ & Interactive Innovation & $\begin{array}{c}\text { Managing the Flow of Technology (Allen,1977); Evolutionary Theory of Economic } \\
\text { Change (Nelson \& Winter, 1977) }\end{array}$ \\
\hline $\mathbf{1 9 8 0}$ & $\begin{array}{c}\text { Innovation, collaboration, interaction of } \\
\text { actors }\end{array}$ & $\begin{array}{c}\text { Actor-Network Theory (Akrich et al, 1988); Kline \& Rosenberg (1986); Innovation } \\
\text { Systems (Freeman, 1982); Lundvall (1985) }\end{array}$ \\
\hline $\mathbf{1 9 9 0}$ & $\begin{array}{c}\text { Innovation \& Networks } \\
\mathbf{2 0 0 0}\end{array}$ & $\begin{array}{c}\text { Techno-Economic Networks (Callon, 1991); Industrial Innovation (FREEMAN e } \\
\text { SOETE, 1997); Powell, 1990; Debresson \& Amesse, 1991; Freeman, 1991) }\end{array}$ \\
\hline $\mathbf{2 0 1 0}$ & Open innovation implementation \& net- \\
works & Chesborough (2003); Gassman (2006); Trott and Hartmann (2009) \\
\hline
\end{tabular}

Table I: Evolution of Innovation \& Collaboration Paradigms from the 1950's (various sources based, on Martin, 20I2)

ISSN: 07 I8-2724. (http://www.jotmi.org)

Journal of Technology Management \& Innovation (c) Universidad Alberto Hurtado, Facultad de Economía y Negocios. 


\section{I.2 Innovation Sociology and the concept of a Tech- no-Economic Network}

Innovation sociology is a sociological approach developed in the 1980s and 1990s to understand and explain innovation processes. According to this view, innovation processes are often marked by uncertainty and high complexity, permeated by a multitude of heterogeneous decisions (often confusing) involving multiple actors and often a certain antagonism and different opinions.

Responding to all this instability and multiplicity it is necessary to improve some skills of interaction, circulation of information, adaptation and flexibility (Akrich et al, 1988). Negotiation processes occur not only related to technical issues but also to social and political matters, and among several categories of actors connected by heterogeneous arrangements.

Sociology of innovation approach was criticized, reinterpreted and reviewed by several authors, including its own creators (Callon, 1999; Latour, 1999; Latour, 2005). Recent reviews reveal that this approach allows an adequate coverage of the multidimensionality of actors and the multiplicity of network logics, along with a great variety of relationship contents and science and technology environment contexts (Smith-Doerr and Powell, 2005).

In the heart of this framework lies the concept of the Techno-Economic Network (TEN), conceived to study and understand innovation processes occurring in European Research Projects (Callon, 199I; 1992; Callon, Laredo and Rabeharisoa, 1992; Callon, Laredo and Mustar, 1995). Callon (199I) defines a Techno-Economic Network - TEN as a "coordinated set of heterogeneous actors" such as government laboratories, technological research centers, private companies, funding organisms, public authorities and end-users. It is a descriptive approach, allowing the understanding of a networked innovation process occurring through interactions and relationships established among the actors, as a representation model of the complex process of generating technological artifacts and innovations. This concept highlights the need for flexible and adaptive forms of coordination of heterogeneous actors so that they could collectively generate and diffuse technological innovations. Coordination strategies are represented by governance forms involving management strategies, contractual models, knowledge sharing practices and communication flows.

Callon (199I) highlights that the central process in a Techno-Economic Network is the translation, that represents the different "understandings" that each actor has about each other. Actor $A$ translates actor $B$ and, the other way around, Actor $B$ translates actor $A$. In within a network each actor translates all of the others with which he established relationships. The intermediaries are translation operators, the inscriptions where the translations are registered. The degree of agreement between the several translations established in within the network determines its degree convergence, that can be represented by two concepts: alignment (agreement of translations) and coordination (regulations and conventions practiced in the network).

Other important concepts related to the morphology of TEN, which were created in order to describe the different configurations of a network and how it influences innovative processes are convergence and irreversibilization.

Convergence refers to the degree of agreement engendered by a series of translations and the various types of the intermediates operating them. In a strongly convergent network, any actor, regardless his category (researcher, engineer, businessman), can mobilize at any time the competences of the network without great adaptations. When the TEN is dispersed, the messages and communications get lost in the way, and translations are less efficient. Two dimensions define the degree of convergence: alignment and coordination. Alignment involves the degree of disagreement in the translation process: less disagreement, more alignment. The alignment can be influenced by the implicit or explicit conventions and practices of the network action; what is called its coordination degree. Coordination relates to the set of rules and conventions that regulate, define and codify translations and coordination strategies. In a heterogeneous network several forms of coordination are put together like market, organization, trust, recognition, and so forth.

On the other side, irreversibilization relates to the translations that occur in within a TEN and the option to return to an initial stage or to predetermine future translations. It is a relational characteristic that involves competition with other possible translations, that would depend of how the actors interact. A durable and robust TEN should resist to the assaults of competing translations and is a synonym of normalization. An irreversible network is filled with norms, rules and standards - and it becomes costly to mobilize new translations.

We consider that the TEN construct offer a solid framework to perform the analysis of how: problems are translated, actors mobilized and organizational mechanisms developed through the interactions that happen in within an inter-organizational network. 


\section{I.3. Collaborative Innovation, Technological Trajec- tories \& Meteorology}

Innovation process follows certain paths according to the economic sector involved (Pavitt, 2003), and also considering the scientific field of study. In the case of Meteorological Sciences, collaborative initiatives among professionals were at the beginning of this scientific field since in the 18th century. Initially these networks were naturally formed by the association between meteorologists who, desiring to expand the scope of their observations, shared with other colleagues the weather data collected by them (Fleming, 1998). Due to the scientific and technological development occurred from the seventeenth century, with the invention and application of numerous measuring equipment such as the barometer and thermometer, the development of collaborative networks was possible (Middleton, 1969).

In the nineteenth century, the invention and spread of the telegraph (from 1850), made possible the transmission of data and forecasts among the nodes of the observation networks that were being built in many European states. Communication through on the Post Office telegraphic network enabled the accumulation of large amounts of data for broader geographical areas, allowing the generation of knowledge and highlighting the importance developing of measurement unit standards and data collection procedures in the field (Barboza, 2002).

At that time, meteorologists realized that, to understand weather conditions, they needed not only records of atmospheric conditions but simultaneous observations made at regular intervals to a central office, what they called synoptic observations. Synoptic weather forecasts, based on empirical measures of atmospheric pressure, began to be calculated and disseminated.

Thus, in the 19th Century, with the strengthening of meteorological observations networks based on the communication infrastructure of the telegraph and the institutionalization of Meteorology sector, meteorological networks improved worldwide.

The developments of Meteorology in the 20th Century had strong influence of Natural Sciences, through theories derived from Mathematics, Physics and Chemistry. This new phase is named the Modern Era of Meteorology, when the numerical weather prediction models were developed, based on solving equations representing atmospheric dynamics as a nonlinear system. The invention of the first computer (around 1950) allowed the calculation of the first numerical weather prediction, using weather data collected in a given region.
It is important to stress that the development of numerical weather prediction models was a collective enterprise involving the collaboration between several institutions of different sectors and countries, and the sharing of financial, administrative and human resources. Some of the organizations involved in this initiative were: U.S. Meteorology Service, the U.S. Navy and Air Force and the Joint Numerical Weather Prediction Unit (JNWPU), formed by researchers from the "Meteorology Project" of the Institute for Advanced Study in Princeton, the "Project Numerical Forecast" of the Geophysics Research Laboratory of the Air Force at Cambridge and the International Meteorological Institute in Stockholm located in Sweden (Harper, 2007).

The first calculations of numerical weather forecasts were possible due to the convergence of several factors such as: the availability of meteorological data, the prediction equations, the processing capacity, international expertise, financial resources and support from various institutions.

The evolution of microelectronics - in the 1990s -generated computers capable of storing data transmitted from stations located in several places and also of processing them producing weather forecasts or other meteorological products, Even if there is still an asymmetry in relation to access to data and information available on the Internet, whether for reasons of infrastructure (unavailable in less favored regions) or economic (in relation to the possibility of affording it), this new informational reality provided broad dissemination of meteorological data and products on a scale never seen before.

Edwards (2004) describes meteorology as a complex technological system that involves the transmission of data from a network of observation stations on land, sea, air and space, and the assimilation of these data by computerized processing centers in real time and its redistribution to other meteorological services located around the world.

In the 20th Century this technological system was marked by the invention of new ways of collecting data (such as altitude observations instruments and remote data generated by new technologies such as radar, sensors and satellite probes), and the existence of various data formats and possibility of high-speed transmission.

The improvement of meteorological instruments increased the accuracy of available data, the transmission easiness to processing centers and the multiplication of data types available for analysis and for forecasting calculations. The development of computer technology and processing capacity and storage, in parallel with the development of measuring instruments, allowed the use of new techniques for processing and also the construction of databases, robust and re- 
liable. One important result of all these innovation is the reliability of the forecast weather, which nowadays is around $98 \%$ for two days (48 hours).

Numerical weather forecasts were applied to prevent climatic disasters, to plan military endeavors and several economic activities, especially in the agricultural sector. The application of meteorology in agriculture is essential, since every facet of agricultural activity depends on the weather. Adverse weather conditions represent about $80 \%$ of the variability that occurs in agricultural production, what makes Agriculture one economic activity most dependent on weather conditions. According to the "Minimum Law", created by Liebig in 1840, "one organism growth is controlled not by the total amount of resources available, but by the scarcest resource", called "limiting factor", and in agriculture, this factor is the climate.

There are many examples of the potential benefits of applied meteorology that farmers can gain to improve efficiency and ensure sustainability of their farm management. They can protect and ensure the continuing health of their crops, livestock and environment, they can increase their yield and the market value of their crops, and solve selected operational problems. This is one of the most important areas of study in Agricultural Sciences, called "Agrometeorology".

\subsection{The field of Agrometeorology in the Brazilian context}

Agrometerology is an interdisciplinary and multidisciplinary applied science, that puts the science of meteorology at the service of agriculture (Mavi and Tupper, 2004), in its various forms and facets, to help with the sensible use of land, to accelerate the production of food, and to avoid the irreversible abuse of land resources (Smith, 1970).

Agrometeorology can be defined as the science investigating the meteorological, climatological, and hydrological conditions that are significant to agriculture, studying their interaction with the objects and processes of agriculture production (Molga, 1962). In this context, it gathers knowledge dispersed in agronomy, soil analysis, biological processes and other aspects associated to agricultural activities in order to reduce climate risks, increase productivity and reduce economic hazards targeting at a sustainable agriculture.

Several meteorological variables - such as rain, radiation, wind velocity, temperature - influence in agriculture efficiency and practices. Temperature and rain, for example can define plant growth, affecting development and yields (Holzkamper et al., 201 I; Kassam et al., 1991). In addition, weather conditions can affect agricultural practices, such as soil preparation, seeding, irrigation, harvesting as well as the relationship between plants and microorganisms, insects, fungi and bacteria, what could favor or hide the occurrence of plagues or diseases, what would require adequate control measures (Ghini et al., 20I I). The availability of a precise and broad agrometeorological database - including, at least, observations of temperature and rain of a given area - is essential for the study and management of agricultural and forestry processes.

The first steps of the Brazilian meteorological science begins at the beginning of the XIX century when the Portuguese royal family moved to Brazil, which by then was a colony. However only in the beginning of the $X X$ century the first public meteorological institute was created, supporting the development of an observational network, the acquisition of modern equipment organization and the development of synoptic methods of weather forecast (BAMBINI, 20I I).

Brazil is the fifth largest country in area (with 8,5 million $\mathrm{km} 2$ ) and is slightly smaller than the entire European continent (10,4 million $\mathrm{km} 2)$. Considering its large territory, the country has large variation of landscapes, topography, climate, soil and presents five time zones. These characteristics (area and climatic and topographical variations) explain the difficulties in obtaining reliable data and weather information for the whole Brazilian territory.

During the last century, several meteorological institutes were formed, spread along several ministries of the Government such as Agriculture, Navy, Air Force and Science and Technology, as well as some observation and monitoring centers linked to regional governments.

The lack of integration and the scarce collaboration among all these federal meteorological centers along with regional ones, and the absence of communication strategies of these public meteorological centers with the population are the institutional challenges faced in this field. There is a great difficulty in coordinating all the actors of the meteorological sector in order to provide and share data to cover the entire country. Since the 1980's, the Federal Government conducted several initiatives to establish specific and integrated directives for meteorological sector. The last one of them is the publication of a National Meteorological and Climatological Policy in 2008, which is under analysis at the Federal Senate. Some technical aspects also influence in the development of the sector: obsolete observation network in several regions, difficulties to access meteorological data (once some regional centers protect and commercialize their meteorological data); lack of homogeneity of data formats; and difficulties in data transmission and storage. 


\section{Method}

A research of exploratory and qualitative nature was conducted through 2009 and $201 \mathrm{I}$ in order to describe and understand the networked innovation processes occurring at an inter-organizational network (BAMBINI, 20II). The research method employed was the case-study (YIN, 2010 ) and the unit of analysis is a specific network formed in $200 \mathrm{I}$ to develop Agritempo system that provides, since 2003, agrometeorological data and information freely at its website on the Internet. This case has been selected considering its high durability of the network and the significant scientific and technological results obtained.

The following research steps were performed: definition of data collection instruments, selection of sources of evidence; mapping of the network; conducting interviews and sending out questionnaires, data analysis. Data was collected through document research and interviews with actors, aiming to give them voice in order to understand the dynamics of the network and identify the different coordination strategies employed: 27 interviews were conducted ( 12 by phone) and 3 subjects were consulted through a written survey.

The analysis was achieved using Innovation Sociology framework, which allowed the understanding of the network dynamics through actors interactions, translation processes and intermediaries generation, applied to the innovation process occurring in the field of agrometeorology. Considering that innovation processes are influenced by the economic and scientific sectors related (Pavitt, 2003), the study considered the specificity of the agrometeorological scientific and professional field. Next section describes the empirical findings of the case-study.

\section{Results}

\section{I Motivations to develop Agritempo system}

The main motivation to develop Agritempo system came from a specific demand of Agriculture Ministry of Brazil for a single website grouping all the agrometeorological data available for Brazilian states and regions. This demand was communicated to the research team of Embrapa Informatics for Agriculture and to Unicamp, that mobilized several other actors to develop an information system supported by a strong database of meteorological data. We can say that there was an inducing role of the government to the formation of this network, as an Induced Innovation Networks (IIN) described by Pellegrin et al, (2010), with Agriculture Ministry playing a central inducing role as user and financial supporter of the network.

One of the main prerequisite for the study and management of agricultural and forestry activities is the availability of a precise and broad agrometeorological database including observations of temperature and rain of a given area. Meteorological information systems allow the supply of information and guidelines that can minimize risks and reduce losses caused by adverse weather conditions, which provokes about $80 \%$ of the variability in agricultural production.

By employing meteorological information systems, farmers and rural extension agents can minimize climatic risks and reduce losses caused by adverse weather conditions, making the right decision from the daily activities of the production process. For example, monitoring the availability of soil water, farmers can decide if it is a good option (or not) manage the soil or plant the crop. And the knowledge of weather forecast support decisions as applying phytosanitary treatments, or irrigation.

So, the information provided by Agritempo assists in planning decisions such as planting dates, selection of more suitable varieties for each region of Brazil, identification of irrigation needs and also to plan pesticide application. Therefore Agritempo can be characterized as a Decision Support System for agriculture (Mavi \& Tupper, 2004).

The system was developed from 2001 to 2003 considering the characteristics of a new informational context marked by the Information Technology Revolution, based on physical and virtual infrastructure formed by a physical network of instruments that collects meteorological data and a technological internet-based information technology network associated with new processing \& data visualization techniques. It is aimed to automatize the entire process of collecting, storing, processing and delivery of agrometeorological data and information. Thus, it can be said that the Agritempo system appears as an important product innovation, providing customized weather information to support the agricultural sector with coverage throughout the Brazilian territory. Is also represents an important process innovation once it automatized several tasks that were performed manually before, so as to provide more accurate and reliable information products.

A complex arrangement of up to 40 organizations supported the development of Agritempo and its database. This network which is a coordinated arrangement of heterogeneous organizations with common objectives is an important organizational innovation. The motivations for the actors in forming this network were varied: the sharing of their own data with peers; the access to data released by other organizations; the use of this database system for studies and its own research; the generation of specific agrometeorological products in collaboration with other institutions; and the use of monitoring products and forecasts for operational activities (especially regarding government services). 


\subsection{Dynamics and Morphology of the network}

As previously cited, a network of up to 40 organizations was formed including various categories of actors such as: 12 research units of Embrapa; several organizations linked to the Federal Government (such as National Agencies, Ministries; Meteorological institutions; State government secretaries); 4 universities; 2 private meteorological companies and I international public organization (Meteorology National Service of Peru).

The arrangement of Agritempo Techno-Economic Network has a great complexity. Some of the elements of that complexity of this TEN are that the actors are dispersed in a wide area (Brazilian territory), that there is a great diversity of types of actors participating (Academic, Government, Private, Individuals), that it was necessary to collect data from several institutions from all Brazilian regions to cover the entire country, and that there are different scientific and technological fields involved with different languages and terms (meteorology, information technology, agricultural sciences, public policy).

Additionally, Agritempo represented a major information technology challenge once it was necessary to promote exchange and storage of several types of data such as numerical values of variables (sent by automatic and conventional meteorological stations) and satellite images captured by a specific sensor. Technological integration of the partners through software development (relating to the flow of data and its processing and storage) and the inter-organizational management strategies favored the coordination of the network.

The institutional origin of the main actors had a great relevance for the network governance. Since 12 of the actors are research centers of Embrapa, it is important to state the influence of this institutional context for the coordination of the TEN formed in this arrangement. Embrapa is a Brazilian federal enterprise that has more than 9.700 employees, divided in 47 research and service centers and 14 administrative units, distributed along the Brazilian territory (http:// www.embrapa.br). The company also has an international research structure (in United States, France, the Netherlands, United Kingdom and South Korea) and also technology transfer projects in Africa and South America.

The strategy of stimulating collaborative research projects in a networked format has been followed by Embrapa since the end of the 1990s. This strategy focuses on selecting and articulating external partners and Embrapa's research centers with complementary competences, resources and objectives to optimize both the company efforts and the research results obtained.
Embrapa has a strong managerial structure and corporate procedures to plan and coordinate its research activities. These procedures have to be followed by all research centers of Embrapa and also by their external partners, and in practice, the network formed to develop Agritempo system was strongly influenced by the dominant management practices of Embrapa, providing a flexible hierarchical structure of project leaders, plan leaders and operational activities responsible persons. Besides some difficulties related to bureaucracy, we consider that the existence of the a dominant institutional context has positively influenced the convergence of Agritempo System network, since there was a clear and known set of norms and practices to be followed by the majority of the actors involved.

Several coordination forms were mapped and coexist in this TEN, such as: trust based relationships, (funded in the previous research project developed before); informal relationships among peers of the agrometeorological field; formal contracting (when there was an important demand of institutionalization of the partnership and data sharing activities); communication practices and flows of knowledge, data and information; and technical, managerial and political leadership. Evidence showed that leadership - either scientific \& technological, political and managerial - played an essential role in dealing and solving communication problems, technical arguments and personal conflicts during the development of the system.

Figure 2 shows the coordination role of Embrapa and Unicamp in defining which actors should be included in the network, dividing scientific and technological activities according to the competences available and dealing with com-

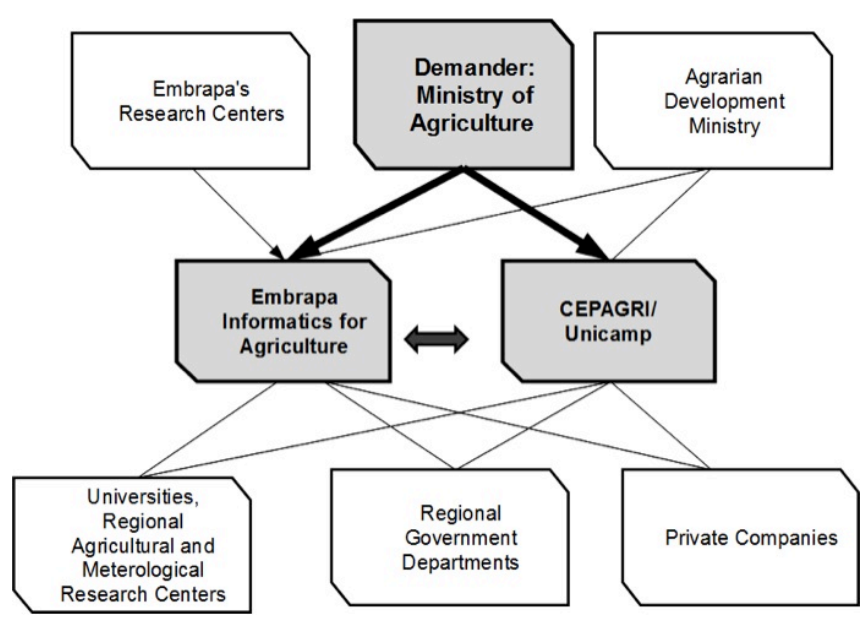

Figure 2 - Representation of the relationships established in the network considering leadership roles pf Unicamp and Embrapa, as well as other the heterogeneous actors that are users and producers of meteorological data 
munication and conflict solving issues. We can say that these two actors provided a central coordination mechanism influencing the entire network.

A practice used to reduce conflicts and confrontations among the actors (specially scientific and technological organizations) was the assignment of responsibilities according to their technical competence. Each actor activities were determined by technical criteria related to their area of expertise with a given agricultural product and/ or region of the country. The coordinators of the network selected partners that represented uniquely each of these criteria, inducing a division of roles and areas of action by technical competence, what minimized eventual disputes. Another strategy employed to select new partners was the availability of meteorological data for a given region, in order to create a robust database.

The alignment (the level of agreement of the translations in the network) is another important aspect of the convergence of this network. It was observed that this TEN possesses high level of alignment once most of its actors, regardless of their position, can mobilize the skills of the network at any time without great cost of translation.

This arrangement was formed in 2002 and it is still active in 2014. It generated several economical products (called intermediaries by Callon, 1992): a technological artifact (Agritempo); several software tools; texts such as papers, reports and technical documents; new knowledge related to agriculture, meteorology and information technology; competences in the form of know-how, personal abilities and skills; money through funding strategies; and hybrid forms like the web system interface and its database. Based on Callon (1992), we could say that the network has a very efficient translation processes, which favors interactions among actors more effectively and productively, resulting in innovation.

This network strength is connected with the great variety of relationships established among the actors, like exchange, production and circulation of intermediaries such as competences, financial resources and rules of action. Alongside, this network merged with a previous and consequently different TEN that also participates in its dynamics.

The strength of these relationships can be explained by the alliances and partnerships that were established since the 1990 s to develop the Agricultural Zoning recommendations. This recommendations resulted from a national public policy promoted by the Brazilian Ministry of Agriculture that indicates low climatic risk planting periods for the most important crops in Brazil by municipality (Assad, 2004). According to Callon (1991), we can say that a TEN may be associated with several others, with whom it exchanges intermediaries, that cross their borders.

\section{Conclusions and Future Developments}

The Agritempo system is a convergent network that generated and circulated several products like a technological artifact, software tools, papers and technical documents; competences; and money through funding. Based on Callon (1992), we could say that the network has a very efficient translation processes, which favors a more effective and productive interactions among actors. The actors (especially those from the science and technological poles) can easily mobilize other actors of the network to solve problems, without many costs and adaptations. There is also a high level of alignment in the network represented by synergistic initiatives, interests and mutual understandings among the actors involved.

The efforts and leadership of the technical teams from Embrapa and Cepagri/Unicamp provided most of the convergence in the network. Other forms of coordination were also employed, comprehending several interaction strategies and management initiatives.

The development of Agritempo system was favored by the dominance of the science and technology poles that were strongly based on Information Technology. There is also a close relationship between science and market poles, with direct interactions between Government (which demanded the system and its database) and the coordination center of this network, formed by individual leaders from Embrapa and Cepagri/Unicamp.

Agritempo's TEN presents a high level of irreversibilization since it was created in 200I, and the system is still in operation in 2014. The irreversibilization of the network is 3 due to the fact that the translations occurring in the network are developed in a sense that strengthens this TEN in a complementary way. Although it is an individual casestudy we consider that this research can stand as a contribution to the study of networked innovation and coordination strategies. This analysis may be relevant to Embrapa or other research institutes that intend to participate in the innovation network.

By providing agrometeorological data and information on the internet, Agritempo system democratized the access to agrometeorological information, reaching a large audience of users like agricultural producers, trade associations and government representatives. Considering the evolution of technological and informational platforms more adapted to the Web 2. paradigm and to the present mobility issues, there is a research initiative already taking place to generate a new version of Agritempo system. 


\section{References}

ADES, C., Figlioli, A., Sbragia, R., Porto, G., Plonsky, G. A., Celadon, K. (2013) Implementing Open Innovation:The Case of Natura, IBM and Siemes. Journal of Technology Management and Innovation, 8, Special Issue ALTEC, 12-25.

AKRICH, M., Callon, M. Latour, B. (1988) A quoi tient le succés des innovations? I: L'art de l' interessement, Gérer et comprendre. Annales de Mines, I I, pp. 4- I7.

ARUJA, G. Collaboration Networks, Structural Holes and Innovation: A longitudinal study. Administrative Science Quarterly, 45, 2000. pp. 425-455.

BAMBINI, M. D. (20I I) Inovação tecnológica e organizacional em agrometeorologia: estudo da dinâmica da rede mobilizada pelo sistema Agritempo. MSc Universidade Estadual de Campinas - Unicamp. 217 p.

BUSH,V. (1945) Science - the Endless Frontier, A Report to the President by Vannevar Bush, Director of the Office of Scientific Research and Development. Washington: United States Government Printing Office. 256p.

CALLON, M. (1999) Actor-Network Theory: the Market Test. I In: Law, J. , Hassard, J.(Eds.) (1999) Actor Network and After. Oxford and Keele: Blackwell and the Sociological Review. pp. 18I-195.

CALLON, M. (1992) "The dynamics of techno-economic networks" in Coombs, R., Saviotti, P. e Walsh, V. (1992). Technological Change and Company Strategies: Economical and Sociological Perspectives. London: Harcourt Brace Jovanovich Publishers. pp. 72-102.

CALLON, M. (1991) Réseaux techno-économiques et irréversibilité. In: Boyer, R., Chavance, B., Godard, O. (199I) Les Figures de L'Irreversibilité em Économie. Paris: Éd. de I' École des Hautes Études em Sciences Sociales. pp. 195-230.

CALLON, M. Laredo, P. Rabeharisoa, V. (1992) The management and evaluation of technological programs and dynamics of tecno-economic networks: the case of the AFME. Research Policy 2I, 1992. p. 215-236.

CALLON, M. Larédo, P. Mustar, P. (1995) Réseaux technicoéconomiques et analyse des effets structuraux In: Callon, M. Larédo, P. Mustar, P. La Gestion Stratégique de la Recherche et de la Tecnologie. Paris: Economica,. p.415-462.

CHESBOROUGH, H. (2003) The Era of Open Innovation. MIT Sloan Management Review. Spring 2003. Retrieved from: http://sloanreview.mit.edu/article/the-era-of-open-innovation/
DEBRESSON, C.Amesse, F. (I99| ) Networks of Innovators: a review and introduction to the issue. Research Policy (20) Pp. 363-379.

EDWARDS, P. N. (2004) “A Vast Machine": Standards as Social Technology. SCIENCE Vol 3047 May 2004. pp. 827-828.

FLEMING, J. R. (1998) Historical Perspectives on Climate Change. New York: Oxford University Press. 194p.

FREEMAN, C. (199I) Network of innovators: a synthesis of research issues. Research Policy (20). pp. 499-5I4.

FREEMAN, C. Soete, L. (2009) A economia da inovação industrial. Campinas, SP: Editora da Unicamp. 816p.

GASSMAN, O. (2006) itorial. Opening up the innovation process: towards an agenda. R\&D Management 36, 3.pp.223228.

GHINI, R. ; Hamada, E. , Bettiol, W. (Orgs.) (20II) Impactos das mudanças climáticas sobre doenças de importantes culturas no Brasil. Jaguariúna: Embrapa Meio Ambiente. 356p.

HOLZKÄMPER, A.; Calanca, P.; Fuhrer, J. (201I) Analyzing climate effects on agriculture in time and space. Procedia Environmental Sciences v.3, n., p. 58-62.

KASSAM A.H.; Van Velthuizen H.T.; Fischer G.W.; Shah M.M. (199I) Agro-egological land resources assessment for agricultural development planning - A case study of Kenya. Resources data base and land productivity - Technical Annex 3- World Soil Resources Reports. Rome: Land and Water Development Division - Food and Agriculture Organization of the United Nations (FAO). 78p.

KLINE, S.J. Rosenberg, N. (1986) An Overview of Innovation. In: Landau, R. Rosenberg. N. The Positive Sum. Washington, National Academy Press. p. 275-305.

LATOUR, B. (1999) On Recalling ANT. In: Law, J. , Hassard, J.(Eds.) (1999) Actor Network and After. Oxford and Keele: Blackwell and the Sociological Review. pp. 15-25.

LATOUR, B. (2005) Reassembling the social: An introduction to actor-network-theory. New York: Oxford University Press. 30lp.

LAW, J. (1999) After ANT:Topology, Naming and Complexity. In: Law, J., Hassard, J.(Eds.) (1999) Actor Network and After. Oxford and Keele: Blackwell and the Sociological Review. Pp.I-I4.

ISSN: 07 I8-2724. (http://www.jotmi.org) 
MARTIN, B.R. (2012) The Evolution of Science Policy And Innovation Studies. Centre for Business Research, University of Cambridge Working Paper No. 432. 75p.

MAVI, H.S., Tupper, G. J. (2004) Agrometeorology. Principles and Aplications of Climate Studies in Agriculture. United States of America:The Haworth Press Inc. 364 p.

MOLGA, M. (1962). Agricultural Meteorology. Part II-Outline of Agrometeorological Problems. Warsaw: Polish Academy of Sciences. $35 \mathrm{Ip}$.

PAVITT, K., 2003. The process of innovation. SEWPS: SPRU Electronic Working Paper Series. Brighton: SPRU, 47p.

POWELL, W. W. Neither market nor hierarchy: Network forms of organization. Research in organizational behavior, 12, 1990. pp.295-336.

POWELL, W.W. Koput, K. W. Smith-Doerr, L. Interorganizational Collaboration and the Locus of Innovation: Networks of Learning in Biotech. Administrative Science Quarterly, 4I, 1996. pp. I I6-145.

PELLEGRIN, I., Balestro, M.V., Valle Junior, J.A., Dias, S.L.V. (2010) Dynamizing Innovation Systems through Induced Innovation Networks:A Conceptual Framework and the Case of the Oil industry in Brazil. Journal of Technology Management and Innovation, 5 (3). ppI5-28.

SMITH, L.P. (1970) Aims and extend of agricultural meteorology. Agricultural Meteorology. v.7, pp. 193-196.

SMITH-DOERR, L., Powell,W.W. (2005) Networks and Economic Life. In: Smelser and R. Swedberg. (Eds.) (2005) The Handbook of Economic Sociology - Second Edition. N.J. Princeton, NJ: Russell Sage Foundation/Princeton University Press. pp. 379-402.

TROTT, P. Hartmann, D. (2009) Why 'Open Innovation' in old wine in new bottles. International Journal of Innovation Management.Vol. I3, No. 4 (Dec. 2009). pp. 7I5-736.

VALKOKARI, K. Paasi, J., Luoma, T. Lee, N. (2009) Beyond open innovation - the concept of networked innovation. Proceedings of the 2nd ISPIM Innovation Symposium, New York City, USA, 6-9 December 2009.

YIN, R. K. Estudo de Caso: planejamento e métodos. Porto Alegre: Bookman, 20 I0. 248p. 